\title{
Sequence-Tagged Sites (STSs) Spanning 4p16.3 and the Huntington Disease Candidate Region
}

\author{
James F. Gusella, * Michael R. Altherr, † Andrea I. McClatchey, ${ }^{*}$ Lynn A. Doucette-Stamm, \\ Dan Tagle, $\S$ Sarah Plummer, † Nicolet Groot, * Glenn Barnes, * Holger Hummerich, \\ Francis S. Collins, $§$ David E. Housman, $\ddagger$ Hans Lehrach, "MarCy E. MaCDonald, ${ }^{\star}$ \\ GILlian BATES," AND JOHN J. WASMUTH† \\ *Neurogenetics Laboratory, Massachusetts General Hospital and Department of Genetics, Harvard Medical School, Charlestown, \\ Massachusetts 02129; †Department of Biological Chemistry, University of California, Irvine, California 92717, \\ $\ddagger$ Department of Biology and Center for Cancer Research, Massachusetts Institute of Technology, Cambridge, \\ Massachusetts 02139; §Howard Hughes Medical Institute, University of Michigan, Ann Arbor, \\ Michigan 48109; and "Imperial Cancer Research Fund, Lincoln's Inn Fields, London WC2A 3PX, United Kingdom
}

Received September 19, 1991; revised December 12, 1991

\begin{abstract}
The generation of sequence-tagged sites (STSs) has been proposed as a unifying approach to correlating the disparate results generated by genetic and various physical techniques being used to map the human genome. We have developed an STS map to complement the existing physical and genetic maps of 4p16.3, the region containing the Huntington disease gene. A total of 18 STSs span over $4 \mathrm{Mb}$ of $4 \mathrm{pl6.3}$, with an average spacing of about $250 \mathrm{~kb}$. Eleven of the STSs are located within the primary candidate $H D$ region of $2.5 \mathrm{Mb}$ between $D 4 S 126$ and $D 4 S 168$. The availability of STSs makes the corresponding loci accessible to the general community without the need for distribution of cloned DNA. These STSs should also provide the means to isolate yeast artificial chromosome clones spanning the $H D$ candidate region. Academic Press, Inc.
\end{abstract}

\section{INTRODUCTION}

The maturing of technologies for manipulating, cloning, and sequencing DNA has made the mapping and sequencing of the entire human genome a feasible goal. Several different approaches are being employed to generate physical maps of human chromosomes, including long-range restriction mapping by pulsed-field gel electrophoresis, ordering of isolated clones by use of irradiation-reduced hybrid lines or fluorescence detectionbased in situ hybridization, and isolation of overlapping clone sets (or "contigs"), particularly using cosmids or yeast artificial chromosomes. The completion of the genome map requires that information from each of the different mapping procedures can be readily compared and related to the genetic linkage map being constructed in parallel. It has been proposed that the use of sequence-tagged sites (STSs), for which specific primer pairs yield a characteristic polymerase chain reaction product as common signposts on the maps, would fulfill the requirement of a "common language" for comparison of the different maps (Olson et al., 1989).

The p16.3 cytogenetic band of chromosome 4 is one of the more extensively mapped regions of the human genome as a result of the search for the defect causing Huntington's disease (Gusella, 1991). The HD gene has been confined to a segment of $4 \mathrm{p} 16.3$ between $D 4 S 10$ and the telomere (Gilliam et al., 1987a). A long-range restriction map of this region includes only one gap and spans $4.5 \mathrm{Mb}$ from $D 4 S 10$ to the telomere (Bućan et al., 1990; Bates et al., 1991). Irradiation-reduced hybrids have also been applied to mapping 4p16.3 (Cox et al., 1989; Doucette-Stamm et al., 1991). Numerous phage and cosmid clones have been mapped to the region and several have yielded DNA polymorphisms, permitting construction of a detailed genetic map (MacDonald et al., 1989a; Youngman et al., 1989; Allitto et al., 1991a). To assist in comparing the evolving physical maps being generated with different cell lines and techniques and to lay the foundation for isolating overlapping $\mathrm{YAC}$ clones for the $H D$ candidate region, we have generated a set of 18 STSs spanning $4 \mathrm{p} 16.3$ at an average spacing of $250 \mathrm{~kb}$.

\section{MATERIALS AND METHODS}

\footnotetext{
Origin of cell lines and clones. HHW416, a human-hamster hybrid containing only human chromosome 4, and HHW693, containing only human 4pter-4p15.1 and 5p15.1-5cen as part of a naturally occurring $t(4 ; 5)$ chromosome with $5 q$ deleted, have been reported previously (Wasmuth et al., 1986). Clones used for generation of primer sets have been used successfully in Southern blot experiments, and their positions on genetic and physical maps have been described previously and are listed in Table 1. STSs have been named by adding ${ }^{*}$ followed by a sequential identitication number to the locus symbol.

DNA sequencing and preparation of oligonucleotides. DNA sequence was obtained by the procedure of Sanger et al. (1977). Primers were synthesized using a Biosearch Cyclone DNA synthesizer or an Applied Biosystems DNA synthesizer or were purchased from Genosys (Houston).
} 
TABLE 1

Description of $4 p 16.3$ Sequence-Tagged Sites

\begin{tabular}{|c|c|c|c|c|c|}
\hline STS & Clone & PCR primer sequences & $\begin{array}{c}\text { PCR } \\
\text { product } \\
\text { size (bp) }\end{array}$ & $\begin{array}{c}\text { PCR } \\
\text { reaction } \\
\text { mix }\end{array}$ & $\begin{array}{c}\text { PCR } \\
\text { program }\end{array}$ \\
\hline$D 4 S 10 * 1$ & G8 & $\begin{array}{l}5^{\prime} \text { GCACCTGGATCTCGGGCTTCTGG } 3^{\prime} \\
5^{\prime} \text { AGAATGGGCTGCGGGAACGGGAG } 3^{\prime}\end{array}$ & 192 & A & 1 \\
\hline$D 4 S 10 * 2$ & 15 & $\begin{array}{l}5^{\prime} \text { CGGGCTGGGTTCCAGCAAGG } 3^{\prime} \\
5^{\prime} \text { CATATGTTGAAGTCCTGCCG } 3^{\prime}\end{array}$ & 213 & $\mathrm{~B}$ & 2 \\
\hline$D 4 S 126 * 1$ & p309 & $\begin{array}{l}5^{\prime} \text { GCATGTACACTGTGAAGCCATAGTA } 3^{\prime} \\
5^{\prime} \text { T'TGCCCTGGCTTCACTGTGCCTCAA } 3^{\prime}\end{array}$ & 184 & $\mathrm{~B}$ & 3 \\
\hline$D 4 S 125 * 1$ & pYNZ32 & $\begin{array}{l}5^{\prime} \text { AGGTGGTTCTGCCCTGAGAGCCTTT } 3^{\prime} \\
5^{\prime} \text { CAGCTGAGGAGGTGCCTCTGCTCCT } 3^{\prime}\end{array}$ & 159 & B & 4 \\
\hline$D 4 S 180 * 1$ & L19ps11 & $\begin{array}{l}5^{\prime} \text { CTGGTTCTCAAGAGTGTCTC } 3^{\prime} \\
5^{\prime} \text { CATAATGTTGGTGGCTGCTG } 3^{\prime}\end{array}$ & 103 & A & 1 \\
\hline$D 4 S 95 * 1$ & pBS674-VR & $\begin{array}{l}5^{\prime} \text { GAGTCTACCGGTGCCAAAAGGAAG } 3^{\prime} \\
5^{\prime} \text { TGGCCTCTCCAGATGGAATGTGCTC } 3^{\prime}\end{array}$ & 1066 & A & 3 \\
\hline$D 4 S 182 * 1$ & pY12Fico2.3 & $\begin{array}{l}\text { 5' GCCTTGGGGCAGGGGCCGGTGAGTA } 3^{\prime} \\
5^{\prime} \text { TCTATGAATTTCAAGGTGGCCATCT } 3^{\prime}\end{array}$ & 213 & $\mathrm{~B}$ & 3 \\
\hline$D 4 S 181 * 1$ & L14ps7 & $\begin{array}{l}5^{\prime} \text { AGGGCCAGTGAGCCTTCAAGCCTTA } 3^{\prime} \\
5^{\prime} \text { AATAAAGTTGTCATGGCCACGTCAT } 3^{\prime}\end{array}$ & 141 & $\mathrm{~B}$ & 3 \\
\hline$D 4 S 43 * 1$ & C39Kpn4.5 & $\begin{array}{l}5^{\prime} \text { GTACCCTTGAAGGGATATATTCCTT } 3^{\prime} \\
5^{\prime} \text { TCTAATGACTAGTGATGTTGGTCAT } 3^{\prime}\end{array}$ & 243 & $\mathrm{~B}$ & 3 \\
\hline$D 4 S 43 * 2$ & LCD450 & $\begin{array}{l}\text { 5' GACTGGTTGTTTGAGGGCGTTG } 3^{\prime} \\
5^{\prime} \text { 'TCCTTGACTCTGCTTCAGC } 3^{\prime}\end{array}$ & 378 & A & 1 \\
\hline 1$) 4 S 166 * 1$ & L6-H10 & $\begin{array}{l}5^{\prime} \text { GGCCTGATCTGAGGTTGTGGAAACG } 3^{\prime} \\
5^{\prime} \text { CTGTACCCAGGAGCATTCTCTCCC } 3^{\prime}\end{array}$ & 895 & A & 1 \\
\hline FGFR $3 * 1$ & pBS385H-A & $\begin{array}{l}5^{\prime} \text { AAAGGTAGCAGTCCAGGC } 3^{\prime} \\
5^{\prime} \text { TGTGTGTCCCAGGCAG } 3^{\prime}\end{array}$ & 202 & A & 1 \\
\hline$D 4 S 168 * 1$ & $\mathrm{E} 4 \mathrm{ps} 2$ & $\begin{array}{l}5^{\prime} \text { TCCCAGGACTCTTCTGGGCACAGGG } 3^{\prime} \\
5^{\prime} \text { CACCAGGGGCTCTCAGGACCT } 3^{\prime}\end{array}$ & 118 & A & 1 \\
\hline$D 4 S 115 * 1$ & $\mathrm{p} 252.3$ & $\begin{array}{l}5^{\prime} \text { ATCAAGTCGAGGGACCTGGGCT } 3^{\prime} \\
5^{\prime} \text { CAGACAGCAGAGTCCACGGACAG } 3^{\prime}\end{array}$ & 164 & A & 1 \\
\hline$I D U A * 1$ & p157.9 & $\begin{array}{l}5^{\prime} \text { GGATCCCTCTGGCATCTC } 3^{\prime} \\
5^{\prime} \text { TACTATCATTACCCATCC } 3^{\prime}\end{array}$ & 230 & $\mathrm{~B}$ & 3 \\
\hline$D 4 S 232 * 1$ & $114 \mathrm{ps} 18$ & $\begin{array}{l}\text { 5' TGCACCCACAACAGCAGGTGGCGAT } 3^{\prime} \\
\text { 5' CATCCGGCGTCTCTCTGGTAATG } 3^{\prime}\end{array}$ & 175 & A & 1 \\
\hline$D 4 S 90 * 1$ & D5 & $\begin{array}{l}5^{\prime} \text { GTCCAGAGGAAGATGTGTAGGGAC } 3^{\prime} \\
5^{\prime} \text { CTACCACACCAGATCGACTAAGC } 3^{\prime}\end{array}$ & 599 & A & 1 \\
\hline$D 4 S 142 * 1$ & $88-18$ & $\begin{array}{l}5^{\prime} \text { CTGGGGAGGCAAAGCCAGACCATAT } 3^{\prime} \\
5^{\prime} \text { GATAGTAGTTCCCACGAGATTCCTC } 3^{\prime}\end{array}$ & 267 & B & 3 \\
\hline
\end{tabular}

Polymerase chain reaction. The polymerase chain reaction and cycling conditions for each primer set are listed in Table 1 as buffer mixture $A$ or $B$ and programs 1-4. Mixture A consists of $67 \mathrm{mM}$ Tris$\mathrm{HCl}, \mathrm{pH} 8.8 ; 6.7 \mathrm{mM} \mathrm{MgCl}_{2} ; 16.6 \mathrm{mM}$ ammonium sulfate; $10 \mathrm{mM}$ $\beta$-mercaptoethanol; $10 \%$ DMSO; and $1.25 \mathrm{mM}$ dNTPs. Mixture $\mathrm{B}$ is $10 \mathrm{mM}$ Tris- $\mathrm{HCl}, \mathrm{pH} 8.3 ; 1.5 \mathrm{mM} \mathrm{MgCl} 2 ; 50 \mathrm{mM} \mathrm{KCl} ; 0.01 \%$ gelatin; and $200 \mu M$ dNTPs. Both sets of reactions included $10 \mathrm{ng} / \mu \mathrm{l}$ of each primer, 0.02 unit/ $\mu \mathrm{l}$ Taq DNA polymerase (Perkin-Elmer/Cetus), and $10 \mathrm{ng} / \mu \mathrm{l}$ genomic DNA and were carried out using one of the following programs designated in Table 1 :

(1) $2^{\prime} @ 94^{\circ} \mathrm{C}, 30 \times\left(1^{\prime} @ 94^{\circ} \mathrm{C}, 1^{\prime} @ 60^{\circ} \mathrm{C}, 1^{\prime} @ 72^{\circ} \mathrm{C}\right) ;$

(2) $2^{\prime} @ 94^{\circ} \mathrm{C}, 30 \times\left(1^{\prime} @ 94^{\circ} \mathrm{C}, 1^{\prime} @ 55^{\circ} \mathrm{C}, 1^{\prime} @ 72^{\circ} \mathrm{C}\right)$

(3) $2^{\prime} @ 94^{\circ} \mathrm{C}, 30 \times\left(1^{\prime} @ 94^{\circ} \mathrm{C}, 1^{\prime} @ 57^{\circ} \mathrm{C}, 3^{\prime}\left(72^{\circ} \mathrm{C}\right)\right.$;

(4) $2^{\prime}\left(94^{\circ} \mathrm{C}, 30 \times\left(1^{\prime} @ 94^{\circ} \mathrm{C}, 1^{\prime} @ 65^{\circ} \mathrm{C}, 3^{\prime} @ 72^{\circ} \mathrm{C}\right)\right.$.

\section{RESULTS}

\section{Generation of STSs}

Individual clones from a variety of sources have been positioned previously on the long-range restriction map of 4p16.3 (Bućan et al., 1990; Whaley et al., 1991; Bates et al., 1991; Lin et al., 1991). The list of those selected for sequence analysis to provide a source of STSs is presented in Table 1 , along with the primer pair, amplifica- tion conditions, and predicted size of the amplification product for each resulting STS.

Each of the STS reactions was initially tested using DNA from HHW416, a human $\times$ hamster hybrid line containing only human chromosome 4 , or from HHW693, a human $\times$ hamster hybrid line containing 4p15.1-4pter as part of a translocation chromosome and DNA from tsH1, the hamster parent (Wasmuth et al., 1986). Since 5p15.1-5cen is the only other human DNA present in HHW693, the chromosome 4 origin of each PCR product could be confirmed using hybrids containing either chromosome 4 (HHW416) or chromosome 5 (HHW599) as the only human DNA. Subsequently, the STS reactions were demonstrated also to yield the expected fragment as the primary product in amplifying human genomic DNA from a variety of sources, such as lymphoblastoid cell lines, placenta, or other tissues, and as the only product from the clone used to generate the corresponding STS.

Figure 1 shows typical examples of PCR amplification products from genomic DNA for several of the STSs 


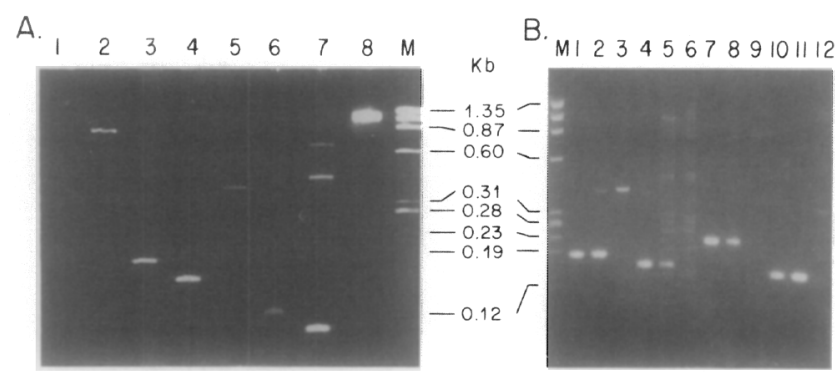

FIG. 1. Representative 4p16.3 STS amplification products: Ethidium bromide-stained gels containing representative PCR products from the STSs listed in Table 1. (A) A 6\% polyacrylamide gel containing the following STS PCR products from HHW693 DNA: lane 1, no DNA control; lane 2, D4S166*1; lane 3, D4S10*1; lane 4, D4S115*1; lane 5, D4S43*2; lane 6,D4S168*1; lane 7,D4S180*1; lane 8, $D 4 S 95^{*} 1$. (B) A $1.2 \%$ agarose gel containing the products of PCR reactions for $D 4 S 126^{*} 1$ (lanes 1-3), D4S125*1, (lanes 4-6), D4S182*1 (lanes 7-9), and D4S181*1 (lanes 10-12) using human DNA (lanes 1, $4,7,10)$, HHW416 DNA (lanes 2, 5, 9, 11), and hamster DNA (lanes $3,6,9,12)$. In $\mathbf{A}$ and $\mathbf{B}$, lane $\mathbf{M}$ contains HaeIII-digested $\phi$ X174 DNA.

reported here. In each case, the major PCR product closely matches the predicted size. Occasionally, a fragment was also amplified from hamster DNA but was readily distinguishable from the human product based on its size. For example, the $\sim 450$-bp product from the $D 4 S 126^{*} 1$ STS reaction seen in both the HHW 416 and hamster lanes is due to amplification of hamster DNA (Fig. 1B, lanes 2 and 3 ), as are the $\sim 450$-bp and $\sim 700$ bp products in the $D 4 S 180^{*} 1$ STS amplification (Fig. $1 \mathrm{~A}$, lane 7) and the numerous light bands in the $D 4 S 125^{*} 1$ amplification (Fig. 1B, lanes 5 and 6 ).

\section{Location of STSs}

The location and corresponding locus symbol for the 18 STSs and for eight polymorphisms for which PCR assays are available are given in Fig. 2. Two STSs are given for the extended D4S10 locus, to which Huntington's disease was first linked (Gusella et al., 1983). $D 4 S 10^{*} 1$ was based on a sequence reported by Stapleton (1988) to cover polymorphic HindIII site 2 and a polymorphic HaeIII site detected by phage clone G8. Base changes at positions 66 and 152 of the 193-bp PCR product are predicted to be the basis for the HindIII and HaeIII RFLPs, respectively, which could now be assayed by digestion of the PCR product with these enzymes. $D 4 S 10^{*} 2$ maps $14 \mathrm{~kb}$ distal to $D 4 S 10^{*} 1$, adjacent to but not spanning a second polymorphic HindIII site, referred to as HindIII 1. The latter can be assayed by PCR using a primer set reported by McIntosh et al. (1989) to produce a $93-\mathrm{bp}$ product crossing this site.

$D 4 S 126^{*} 1$ was generated using the sequence of a random subclone from cosmid BJ14 (Allitto et al., 1991a). This segment falls within a region of increased recombination between $D 4 S 10$ and $D 4 S 125$ and lies near the centromeric limit of the candidate region for $H D$. $D 4 S 125^{*} 1$ was derived from the sequence adjacent to a variable number of tandem repeats (VNTR) polymorphism (Nakamura el al., 1988). The VNTR itself can be assayed by PCR of a much larger product (1400-2200 bp) using primers designed by Richards et al. (1991). $D 4 S 180^{*} 1$ is located in cosmid L19 at the $D 4180$ locus, distal to the region of increased recombination (Lin et al., 1991).

$D 4 S 95^{*} 1$ was designed to span a large single-copy sequence adjacent to the VNTR at this locus (Wasmuth et al., 1988). The resulting PCR product overlaps extensively with the single-copy probe, pBS674D, used in Southern blot analysis of the VNTR. It does not overlap, however, with the 990 to 1600 -bp PCR product of the primer set reported by Allitto et al. (1991b) used for PCR assay of the VNTR. D4S9.5*1 lies within the region of 4 p16.3 that displays linkage disequilibrium with $H D$ (MacDonald et al., 1991a; Snell et al., 1989; Theilmann et al., 1989).

$D 4 S 182^{*} 1$ and $D 4 S 181^{*} 1$ were derived from subclones of cosmids Y12 and L14, respectively (Lin et al., 1991). $D 4 S 182^{*} 1$ is adjacent to a VNTR polymorphism that has yet to be sequenced. $D 4 S 181^{*} 1$ maps within the 250 $\mathrm{kb}$ Not I fragment distal to $D 4 S 182$, but has not yet been localized more precisely. This will require the more detailed restriction map of this segment that will be generated from YAC cloning of the region.

Two STSs are reported for the extended locus $D 4 S 43$, which spans $170 \mathrm{~kb}$. The more centromeric $D 4 S 43^{*} 1$ was generated from the sequence adjacent to the VNTR polymorphism detected by probe pKP1.65 (MacDonald et al., 1989b). We have recently developed a PCR assay for this polymorphism that produces products ranging from 184 to $478 \mathrm{bp}$ in size (Horn et al., 1991). Primers for $D 4 S 43^{*} 2$ were generated from the sequence of the anonymous cDNA, LCD2, reported in Gilliam et al. (1987b). This STS is located near the telomeric end of D4S43, approximately $85 \mathrm{~kb}$ distal to $D 4 S 43^{*} 1$. Although we have not sequenced the PCR product, the correspondence to the predicted size suggests that it probably contains little or no intron seyuence, but rather derives from a single exon.

$D 4 S 166^{*} 1$ is located in a clone that spans the distal breakpoint of an interstitial deletion chromosome that splits 4p16.3 into proximal and distal portions and has been used in regional somatic cell hybrid mapping panels (Whaley et al., 1991). FGFR3*1 corresponds to the sequence of the single-copy probe pBS385H-A, which formerly defined the D4S99 locus (Smith et al., 1988). This STS sequence has recently been shown to form part of the 3' untranslated region of the mRNA transcript of a fibroblast growth factor receptor gene. Consequently, this locus has been renamed FGFR3 (Thompson et al., 1991).

$D 4 S 168^{*} 1$ was generated from a single-copy subclone of cosmid E4, the cloned segment closest to the centromeric side of the remaining gap in the long-range restriction map of $4 \mathrm{p} 16.3$ (Whaley et al., 1991). D4S115*1 was derived from single-copy sequence immediately adjacent to another VNTR polymorphism (MacDonald et al., 1989b). We are currently optimizing a PCR assay for this VNTR to complement those developed for the more 

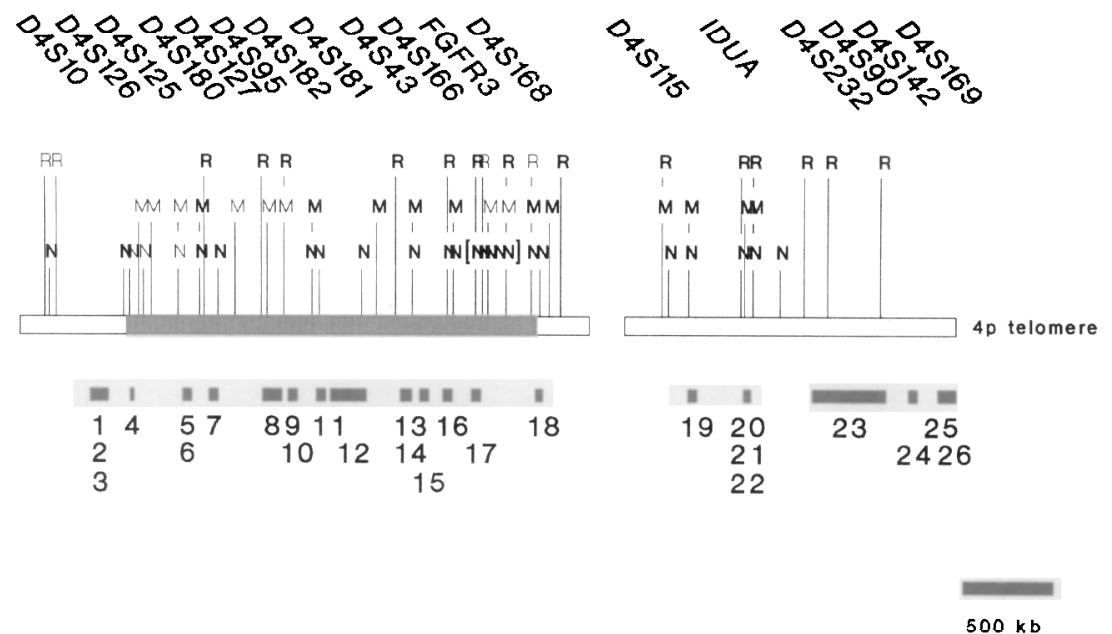

FIG. 2. Physical map locations of 4 p16.3 STS and polymorphism PCR assays. The locations of 18 new STSs (listed in Table 1), two site polymorphisms, two dinuclentide repeat polymorphisms, and four VNTR polymorphisms for which PCR assays have been established are shown below the long-range restriction map of $4 \mathrm{p} 16.3$ with a black line to indicate the smallest interval to which each has been localized. The corresponding locus numbers are given above the map. The proximal and distal portions of the map are separated by a gap of unknown size, where fragments have not yet been visualized. 'The map of the proximal region is drawn from Bates et al. (1991), Lin et al. (1991), and Whaley et al. (1991), and the map of the distal region is drawn from Whaley et al. (1991). Sites (N, NotI; M, MluI; R, NruI) prone to partial digestion are shown in lighter typeface. The Huntington disease gene candidate region (Bates et al., 1991) is shown as the cross-hatched portion of the map. Square brackets around the NotI sites at FGFR3 denote the presence of additional sites that have not all been mapped precisely. The PCR assays shown in the figure are: $1, D 4 S 10^{*} 1 ; 2, D 4 S 10^{*} 2 ; 3, D 4 S 10 \mathrm{HindIII}$ polymorphism assay (McIntosh et al., 1989); 4, D4S126*1; 5, D4S125*1; 6, D4S125 VN'I'K assay (Richards et al., 1991); 7, D4S180*1; 8, D4S127 dinucleotide repeat assay ('laylor et al., 1991); 9, L4S95*1; 10, D4S95 VNTR assay (Allitto et al., 1991b); 11, D4S182*1; 12,D4S181*1; 13,D4S43*1; 14, D4S43 VNTR assay (Horn et al., 1991); 15, D4S43*2; 16, D4S166*1; 17, FGFR3*1; 18, D4S168*1; 19, D4S115*1; 20, IDUA*1; 21, IDUA KpnI polymorphism assay (Scott et al., 1991a); 22, IDUA VNTR assay (Scott et al., 1991b);23, D4S232*1; 24,D4S90*1;25,D4S142*1; and 26, D4S169 dinucleotide repeat assay (Pritehard et al., 1991).

centromeric loci (Allitto et al., in preparation). Together, $D 4 S 168^{*} 1$ and $D 4 S 115^{*} 1$ may permit the isolation of YAC clones that will span the gap in the physical map, which has not been bridged by other techniques.

$I D U A^{*} 1$ lies within the $D 4 S 111$ locus, which has recently been renamed IDUA, encoding $\alpha$-L-iduronidase, the disease gene in Hurler syndrome (MacDonald et al., 1991b). Two other segments can be amplified from this locus, one crossing a polymorphic KpnI site (Scott et al., 1991a) and a second spanning a VNTR polymorphism (Scott et al., 1991b). D4S232*1 is from cosmid I14, which lies within a $400-\mathrm{kb}$ segment of the telomeric NotI fragment of $4 p$ (Whaley et al., 1991), but has not been assigned more precisely due to differences in methylation patterns affecting the $\mathrm{NruI}$ sites in pulsed-field gel mapping of this region. It is probably located close to PDEB, encoding the $\beta$ polypeptide of cGMP phosphodiesterase, the human homologue of the mouse $r d$ gene (Weber et al., 1991; Bowes et al., 1990).

$D 4 S 90^{*} 1$ was generated from the single-copy probe D5, which detects RFLP with HincII and StuI (Youngman et al., 1989). This locus is currently the most telomeric marker that has been formally placed on the linkage map of the chromosome. The PCR product crosses both a HincII and a StuI site within D5, but we have not determined whether either of these represents a polymorphic site. D4S142*1 was derived from 88-18, a single-copy probe detecting an MspI RFLP and located at the proximal end of a YAC clone spanning the $100 \mathrm{~kb}$ that includes the telomere of $4 \mathrm{p}$ (Bates et al., 1990). It is located proximal to the recently reported D4S169 locus, for which a simple-sequence repeat can be assayed by PCR (Pritchard et al., 1991).

\section{DISCUSSION}

The average spacing between our new STSs from $D 4 S 10$ to the telomere is about $250 \mathrm{~kb}$, with the density being highest in the HD candidate region. The most notable segments without STSs are the $450 \mathrm{~kb}$ between $D 4 S 180$ and D4S95 and the gaps of indeterminate size between IDUA, D4S232, and D4S90. The first of these gaps contains a dinucleotide repeat polymorphism at $D 4 S 127$ for which a PCR reaction is available (Taylor $e t$ al., 1992). Filling the gaps between IDUA, D4S232, and $D 4 S 90$ will then require a more specific positioning of D4S232. Also unrepresented is the region between D4S168 and D4S115 for which pulsed-field fragments have yet to be visualized. It is unlikely that this unmapped gap is large, given the number of random clones already isolated from $4 \mathrm{p} 16.3$, and it may be possible to cross it by isolating YAC clones using the D4S168 and D4S115 primer sets.

Taken together with the single-site, dinucleotide repeat, and VNTR polymorphisms for which PCR reactions have been worked out, the 18 S'TSs reported here bring to 26 the number of PCR assays that could be used to screen for YACs in 4p16.3. The 11 new STSs between and including D4S126 and $D 4 S 168$ should prove sufficient to isolate YAC clones spanning most or all of the $H D$ candidate region (Bates et al., 1991). Moreover, the density of STSs in the segment can be increased if 
needed by developing additional primer sets from the ends of YACs as they are isolated. We have already isolated YAC clones using the D4S95 and D4S166 STS assays and are pursuing the goal of cloning the $H D$ candidate region and the rest of $4 \mathrm{p} 16.3 \mathrm{in}$ its entirety. Of more immediate impact, the development of these 18 STSs throughout 4p16.3 makes the corresponding loci and their surrounding regions readily accessible to the entire research community without the cost or difficulty of distributing cloned DNAs.

\section{ACKNOWLEDGMENTS}

The authors thank Dr. Phyllis McAlpine for helpful suggestions concerning the naming of STSs. This work was supported by PHS Grants HG00169 and NS16367 (J.F.G.) and HG00320 and NS25631 (J.J.W.). Additional funding was received from the Hereditary Disease Foundation, the W. M. Keck Foundation, the Joan and William Schreyer Research Fund to Cure Huntington's Disease, and the Huntington's Disease Society of America.

\section{REFERENCES}

Allitto, B. A., MacDonald, M. E., Bucan, M., Richards, J., Romano, D., Whaley, W. L., Falcone, B., Ianazzi, J., Wexler, N. S., Wasmuth, J. J., Collins, F. S., Lehrach, H., Haines, J. L., and Gusella, J. F. (1991a). Increased recombination adjacent to the Huntington's disease-linked D4S10 marker. Genomics 9: 104-112.

Allitto, B. A., Horn, G. T., Altherr, M. R., Richards, B., McClatchey, A. I., Wasmuth, J., and Gusella, J. F. (1991b). Detection by PCR of the VNTR polymorphism at D4S95. Nucleic Acids Res. 19: 4015.

Bates, G. P., MacDonald, M. E., Baxendale, S., Sedlacek, Z., Youngman, S., Romano, D., Whaley, W. L., Allitto, B. A., Poustka, A., Gusella, J. F., and Lehrach, H. (1990). A YAC telomere clone spanning a favoured location of the Huntington's disease gene. Am. $J$. Hum. Genet. 46: 762-775.

Bates, G. P., MacDonald, M. E., Baxendale, S., Youngman, S., Lin, C., Whaley, W. L., Wasmuth, J. J., Gusella, J. F., and Lehrach, H. (1991). Defined physical limits of the Huntington's disease gene candidate region. Am. J. Hum. Genet. 49: 7-16.

Bowes, C., Li, T., Danciger, M., Baxter, L. C., Applebury, M. L., and Farber, D. B. (1990). Retinal degeneration in the $r d$ mouse is caused by a defect in the $\beta$-subunit of rod cGMP phosphodiesterase. Nature 347: 677-680.

Bućan, M., Zimmer, M., Whaley, L., Poustka, A., Youngman, S., Allitto, B., Ormondroyd, E., Smith, B., Pohl, T. I.., MacDonald, M. Bates, G., Richards, J., Volinia, S., Gilliam, C., Sedlacek, Z., Collins, F., Wasmuth, J., Shaw, D., Gusella, J., Frischauf, A. M., and Lehrach, H. (1990). Physical maps of $4 \mathrm{p} 16.3$, the area expected to contain the Huntington disease mutation. Genomics 6: 1-16.

Cox, D. R., Pritchard, C. A., Uglum, E., Casher, D., Kobori, K., and Myers, R. M. (1989). Segregation of the Huntington disease region of human chromosome 4 in a somatic cell hybrid. Genomics 4: 397 407.

Doucette-Stamm, L., Riba, L., Handelin, B., Difilippantonio, M., Ward, D., Wasmuth, J. J., Gusella, J. F., and Housman, D. (1991). Generation and characterization of irradiation hybrids of human chromosome 4. Somat. Cell Mol. Genet. 17.

Gilliam, T. C., Tanzi, R. E., Haines, J. L., Bonner, T. I., Faryniarz, A. G., Hobbs, W. J., MacDonald, M. E., Cheng, S. V., Folstein, S. E., Conneally, P. M., Wexler, N. S., and Gusella, J. F. (1987a). Localization of the Huntington's disease gene to a small segment of chromosome 4 flanked by $D 4 S 10$ and the telomere. Cell 50: $565-571$.

Gilliam, T. C., Bucan, M., MacDonald, M. E., Zimmer, M., Haines, J. L., Cheng, S. V., Pohl, T. M., Whaley, W. L., Allitto, B. A., Faryniarz, A., Wasmuth, J. J., Frischauf, Conneally, P. M., Lehrach, H., and Gusella, J. F. (1987b). A DNA segment encoding two genes very tightly linked to Huntington's disease. Science 238: 950-952.

Gusella, J. F. (1991). Huntington's disease. Adv. Hum. Genet. 20: 125151.

Gusella, J. F., Wexler, N. S., Conneally, P. M., Naylor, S., Anderson, M. A., Tanzi, R. E., Watkins, P. C., Ottina, K., Wallace, M., Sakaguchi, A., Young, A., Shoulson, I., Bonilla, E., and Martin, J. B. (1983). A polymorphic DNA marker genetically linked to Huntington's Disease. Nature 306: 234-238.

Horn, G. T., McClatchey, A. I., Richards, B., MacDonald, M. E., and Gusella, J. F. (1991). Detection by PCR of a VNTR polymorphism at D4S43. Nucleic Acids Res. 19: 4772.

Lin, C. S., Altherr, M., Bates, G. P., Whaley, W. L., Read, A. P., Harris, R., Lehrach, H., Wasmuth, J. J., Gusella, J. F., and MacDonald, M. E. (1991). New DNA markers in the Huntington's disease gene candidate region. Somat. Cell Mol. Genet. 17.

MacDonald, M. E., Haines, J. L., Zimmer, M., Cheng, S. V., Youngman, S., Whaley, W. L., Bucan, W. L., Allitto, B. A., Smith, B., Leavitt, J., Poustka, A. M., Harper, P., Lehrach, H., Wasmuth, J. J., Frischauf, A. M., and Gusella, J. F. (1989a). Recombination events suggest possible locations for the Huntington's disease gene. Neuron 3: $183-190$.

MacDonald, M. E., Cheng, S. V., Zimmer, M., Haines, J. L., Poustka, A. M., Allitto, B. A., Smith, B., Whaley, W. I.., Romano, D., Jagadeesh, J., Lehrach, H., Wasmuth, J. J., Frischauf, A. M., and Gusella, J. F. (1989b). Clustering of multi-allele DNA markers near the Huntington's Disease Gene. J. Clin. Invest. 84: 1013-1016.

MacDonald, M. E., Lin, C. S., Srinidhi, L., Bates, G. P., Altherr, M., Whaley, W. L., Lehrach, H., Wasmuth, J. J., and Gusella, J. F. (1991a). Complex patterns of linkage disequilibrium in the Huntington disease region. Am. J. Hum. Genet. 49: 723-734.

MacDonald, M. E., Scott, H. S., Whaley, W. L., Pohl, T., Wasmuth, J. J., Lehrach, H., Morris, C. P., Frischauf, A.-M., Hopwood, J. J., and Gusella, J. F. (1991b). Huntington disease-linked locus D4S111 exposed as the $\alpha$-L-iduronidase gene. Somat. Cell Mol. Genet. 17: 421-425.

McIntosh, I., Curtis, A., Millan, F. A., and Brock, D. J. (1989). Prenatal exclusion testing for Huntington disease using the polymerase chain reaction. Am. J. Med. Genet. 32: 274-276.

Nakamura, Y., Culver, M., O'Connell, P., Leppert, M., Lathrop, G. M., Lalouel, J. M., and White, R. (1988). Isolation and mapping of a polymorphic DNA sequence (pYNZ32) on chromosome 4p [D4S125]. Nucleic Acids Res. 16: 4186.

Olson, M., Hood, L., Cantor, C., and Botstein, D. (1989). A common language for physical mapping of the human genome. Science 245: 1434-1435.

Pritchard, C., Cox, D. R., and Myers, R. M. (1991). Dinucleotide repeat polymorphism located at D4SI69. Nucleic Acids Res. 19: 6347.

Richards, B., Horn, G. T., Merrill, J. J., and Klinger, K. W. (1991). Characterization and rapid analysis of the highly polymorphic VNTR locus D4S125 (YNZ32), closely linked to the Huntington disease gene. Genomics 9: 235-240.

Sanger, F., Nicklen, S., and Coulson, A. R. (1977). DNA sequencing with chain-terminating inhibitors. Proc. Natl. Acad. Sci. USA 74: $5463-5467$

Scott, H. S., Nelson, P. V., Hopwood, J., and Morris, C. P. (1991a). PCR of a KpnI RFLP in the $\alpha$-L-iduronidase (IDUA) gene. Nucleic Acids Res. 19: 5796.

Scott, H. S., Nelson, P. V., Hopwood, J., and Morris, C. P. (1991b). PCR of a VNTR linked to mucopolysaccharidosis type I and Huntington disease. Nucleic Acids Res 19: 6348.

Smith, B., Skarecky, D., Bengtsson, U., Magenis, R. E., Carpenter, N., and Wasmuth, J. J. (1988). Isolation of DNA markers in the direction of the Huntington disease gene from the G8 locus. Am.J. Hum. Genet. 42: 335-344.

Snell, R. G., Lazarou, L., Youngman, S., Quarrell, O. W. J., Wasmuth, J. J., Shaw, D., and Harper, P. S. (1989). Linkage disequilibrium in 
Huntington's disease: An improved localization for the gene. $J$. Med. Genet. 26: 673-675.

Stapleton, P. M. (1988). Sequence analysis of three polymorphic regions in the human genome detected by the G8 probe for RFLPs associated with Huntington's disease. Nucleic Acids Res. 16: 2735.

'Iaylor, S. A. M., Barnes, G. T., MacDonald, M. E., and Gusella, J. F. (1992). A dinucleotide repeat polymorphism at the D4S127 locus. Hum. Mol. Genet, in press.

Theilmann, J., Kanani, S., Shiang, R., Robbins, C., Quarrell, O., Huggins, M., Hedrick, A., and Hayden, M. (1989). Non-random association between alleles detected at D4S95 and D4S98 and the Huntington's disease gene. J. Med. Genet. 26: 676-681.

Thompson, L. M., Plummer, S., Schalling, M., Altherr, M. R., Gusella, J. F., Housman, D. E., and Wasmuth, J. J. (1991). A gene encoding a fibroblast growth factor receptor isolated from the Huntington disease region of chromosome 4. Genomics 11: 1133-1142.

Wasmuth, J. J., Carlock, L. R., Smith, B., and Immken, L. L. (1986). A cell hybrid and recombinant DNA library that facilitate identification of polymorphic loci in the vicinity of the Huntington disease gene. Am. J. Hum. Genet. 39: 397-403.
Wasmuth, J. J., Hewitt, J., Smith, B., Allard, G., Haines, J. L., Skarecky, D., Partlow, E., and Hayden, M. R. (1988). A highly polymorphic locus very tightly linked to the Huntington's disease. Nature 332: 734-736.

Weber, B., Riess, O., Hutchinson, G., Collins, C., Lin, B., Kowbel, D., Andrew, S., Schappert, K., and Hayden, M. R. (1991). Genomic organization and complete sequence of the human gene encoding the $\beta$-subunit of the cGMP phosphodiesterase and its localization to 4p16.3. Nucleic Acids Res. 19: 6263-6268.

Whaley, W. L., Bates, G. P., Novelletto, A., Sedlacek, Z., Cheng, S., Romano, D., Ormondroyd, E., Allitto, B., Lin, C., Youngman, S., Baxendale, S., Bucan, M., Altherr, M., Wasmuth, J., Wexler, N. S., Frontali, M., Frischauf, A.-M., Lehrach, H., MacDonald, M. E., and Gusella, J. F. (1991). Mapping of cosmid clones in the Huntington's disease region of chromosome 4. Somat. Cell Mol. Genet. 17: 83-91.

Youngman, S., Sarafarazi, M., Bucan, M., MacDonald, M., Smith, B., Zimmer, M., Gilliam, C., Frischauf, A. M., Wasmuth, J. J., Gusella, J. F., Lehrach, H., Harper, P. S., and Shaw, D. J. (1989). A new DNA marker $[D 4 S 90]$ is terminally located on the short arm of chromosome 4 close to the Huntington's disease gene. Genomics 5: 802-809. 